\title{
Meningkatkan Pemahaman Masyarakat tentang Peran Pegadaian Syariah dalam Menyukseskan Program Pemulihan Ekonomi Nasional pada Masa Pandemi Covid19
}

\author{
*Arif Zunaidi \\ Fakultas Ekonomi dan Bisnis Islam Institut Agama Islam Negeri Kediri \\ *E-mail : arifzunaidi@,iainkediri.ac.id
}

DOI: https://doi.org/10.21107/pangabdhi.v7i2.11424

Naskah diterima 20 Juli 2021, Revisi 5 Agustus 2021, Terbit 29 Oktober 2021

\begin{abstract}
Abstrak
Perekonomian dunia pada saat pandemi Covid19 ini mengalami pelambatan. Untuk bisa bangkit kembali, masing-masing negara berjuang untuk menormalkan aktivitas perekonomiannya melalui berbagai kebijakan atau stimulus-stimulus. Sebagai bagian dari lembaga keuangan yang memiliki peran untuk meningkatkan perekonomian, pegadaian syariah melalui program pemulihan ekonomi nasional terutama produk rahn pegadaian yang dimiliki berusaha untuk berperan aktif untuk meningkatkan perekonomian negara. Pengabdian ini menggunakan konsep ceramah, dengan memberikan fakta-fakta tentang peran pegadaian syariah pada pertumbuhan ekonomi Indonesia pada saat pandemi. Kegiatan pengabdian ini melalui beberapa tahapan, mulai dari perencanaan, tahap pelaksanaan dan tahan evaluasi. Harapan dari program pengabdian masyarakat ini adalah agar pemahaman masyarakat meningkat, khususnya pengetahuan tentang peran pegadaian syariah pada saat pandemi Covid19. Pengabdian ini menghasilkan pemahaman masyarakat meningkat dan bahkan mereka menjadi lebih paham dengan peran pemerintah dalam memulihkan perekonomian melalui stimulus yang diberikan melalui lembaga keuangan syariah non bank, salah satunya dengan melalui pegadaian syariah.
\end{abstract}

Kata Kunci : pegadaian syariah, covid19, program pemulihan ekonomi nasional

\begin{abstract}
During the COVID-19 epidemic, the worldwide economy was slowing down. Each country tries to normalize its economic activity through various policies or stimulants in order to be able to bounce back. Sharia pawnshops, as part of a financial institution with a function to play in contributing to economic growth, attempt to play a crucial role in the national economic recovery program, specifically with rahn pawnshop items. This service uses the lecture format by providing information about the role of sharia pawnshops in Indonesia's productivity expansion during the pandemic. This service activity is utilized for various purposes, starting with planning and progressing to monitoring and development. The purpose of this community service program is to make people more aware, notably of the role of sharia pawnsh. This service increased public understanding, and they became more aware of the government's role in trying to revive the economy through stimulus provided by non-bank Islamic financial institutions, one of which was sharia pawnshops.Keywords: Up to six keywords should also be included.
\end{abstract}

Key Words : sharia pawnshop; Covid-19; national economic recovery program

\section{PENDAHULUAN}

Pandemi Covid 19 saat ini membuat beberapa sektor di semua negara mengalami kemerosotan. Sektor kesehatan, sektor sosial, pariwisata dan sektor ekonomi dan bisnis negara mengalami hal yang sama (Sugihamretha, 2020). Dengan fakta tersebut maka setiap negara memiliki beberapa kebijakan yang merupakan bagian dari stimulus untuk mengembalikan keadaan seperti sebelum terjadinya pandemi. Berdasarkan laporan keuangan yang dipublish oleh pegadaian, di semua aspek kegiatan pada perusahaan saat ini berjuang melawan pandemi melalui beberapa manajemen bertahan hidup di masa krisis, pegadaian justru melakukan penguatan manajemen untuk terus berkembang melalui beberapa program yang diprediksi bermanfaat bagi pertumbuhan perekonomian negara (Pegadaian, 2020).

Data dari kinerja pegadaian selama pandemi mengalami peningkatan selama pandemi berlangsung. Jika banyak perusahaan mengalami penurunan dari segi laba, pegadaian 
justru menunjukkan peningkatan laba ke arah positif. Sebagai bagian yang tidak boleh dilupakan adalah bahwa untuk menjadi saat ini pada masa pandemi sekarang ini perusahaan haruslah mengedepankan manajemen resiko, khususnya pada coverage ratio, sekaligus perusahaan berusaha tetap untuk meningkatkan aset produktifnya (Pegadaian, 2020).

Pada saat pandemi sekarang ini setiap warga dan seluruh elemen yang ada dalam sebuah negara dituntut untuk berperan aktif untuk dapat berkontribusi dalam pemulihan ekonomi nasional. Pegadaian sendiri sebagai lembaga keuangan non-bank memiliki andil dalam mendukung program pemulihan ekonomi nasional. Melalui program pinjaman modal produktif pegadaian menyasar para pelaku UMKM agar dapat bangkit dan produktif pada saat pandemi. Program ini adalah bagian dari penyaluran subsidi yang dilakukan oleh pemerintah dalam bentuk subsidi kredit (Pegadaian, 2020). Kondisi pandemi saat ini mengharuskan pelaku ekonomi dan bisnis bertindak dinamis sekaligus adaptif terhadap segala macam perubahan. Kebijakan yang tepat akan mempengaruhi kelangsungan bisnis. Oleh karena itu, prinsip kehati-hatian tetaplah menjadi prioritas utama, khususnya dalam melindungi sumber daya manusia (SDM) yang dimiliki oleh perusahaan.

Selain itu, untuk meningkatkan perekonomian negara, pegadaian juga meluncurkan program gadai peduli. Program ini juga bagian dari bantuan pemerintah untuk peningkatan modal usaha masyarakat pada saat pandemi. Selama pandemi, pegadaian syariah juga meluncurkan program rahn dengan mekanisme nasabah dapat memberikan barang sebagai jaminan berupa emas perhiasan, emas batangan, berlian, elektronik, kendaraan dan barang bergerak lainnya, untuk mendapatkan pembiayaan dari pegadaian (Sari, 2020).

Sebagai mahasiswa yang memiliki konsern pada keuangan syariah, pengetahuan tentang peran pegadaian pada masa pandemi tentu memberikan tambahan pengetahuan yang berguna bagi perkembangan proses belajar di perguruan tinggi. Mahasiswa yang dituntut untuk berfikir kritis dan kreatif, mahasiswa haruslah dapat menemukan dan mengumpulkan data sebagai bahan untuk analisis atau sintesis data. Selain itu juga dituntut untuk mengetahui isu dan fakta untuk membedakan dan memilahmilah data sebagai bagian dari proses pemecahan masalah. Dengan semua proses ini tentunya mahasiswa diajak untuk berfikir optimal (Johnson, 2011). Dalam tatanan berfikir optimal, hal ini termasuk dalam ketrampilan berfikir tingkat tinggi keterampilan berpikir tingkat tinggi atau Higher Order Thinking Skill (HOTS). Berpikir tingkat tinggi menggunakan pemikiran secara luas untuk menemukan tantangan baru. Pemikiran tingkat tinggi menuntut seseorang untuk menerapkan informasi atau pengetahuan baru yang dia dapatkan dan memanipulasi informasi untuk mencapai kemungkinan jawaban dalam situasi baru (Sumar \& Sumar, 2020).

Pada masa pandemi sekarang ini, banyak informasi positif dan negatif tentang peran negara dalam menanggulangi keadaan ini. Mengetahui hal ini maka mahasiswa akan lebih terbuka pada setiap kebijakan yang diambil oleh pemerintah, baik kebijakan langsung atau pun tidak langsung. Dengan latar belakang di atas, maka sangat penting untuk memberikan ilmu tambahan tentang pengetahuan peran pegadaian syariah bagi peningkatan ekonomi pada masa pandemi.

\section{METODE}

Pengabdian masyarakat ini menggunakan konsep ceramah melalui kajian yang diselenggarakan secara online melalui aplikasi Google meets. Dengan konsep ini diharapkan para peserta dapat lebih mudah memahami tentang tema yang dipilih, yaitu peran pegadain syariah dalam meningkatkan perekonomian di saat pandemi Covid 19. Guna kelancaran acara, tim menggunakan skema sebagai berikut:

\section{Tahap Persiapan.}

Pada tahap ini maka melakukan koordinasi dengan beberapa pihak, terutama bagian kegiatan yang membuat acara dan penjadwalan kegiatan. Selain itu juga mengamati situasi objek sasaran yang nantinya akan menjadi tempat pengabdian. Selanjutnya melakukan beberapa hal lain, yaitu:

a. Koordinasi dengan mitra

Pada tahap ini maka tim berkoordinasi dengan mitra, dalam hal ini adalah mahasiswa yang berasal dari kampus Universitas KH. Wahab Hasbullah Jombang. Koordinasi ini untuk mencari kesepakatan tentang konsep dan acara pelaksanaannya.

b. Penyusunan bahan pelatihan media

Pada tahap ini maka tim mempersiapkan media yang akan digunakan dalam penyampaian materi. Hal-hal yang digunakan untuk penyampaian materi dipersiapkan. 
c. Publikasi Kegiatan

Hal lain yang dilakukan untuk kelancaran kegiatan pengabdian ini yaitu dengan mengedarkan informasi rencana kegiatan kepada target. Publikasi ini dilakukan melalui beberapa group yang ada di kampus Unwaha.

\section{Tahap pelaksanaan}

a. Persiapan alat dan bahan

Persiapan pertama yang dilakukan untuk aktivitas ini adalah menyiapkan semua kebutuhan yang akan digunakan pada saat acara berlangsung, meliputi komputer, PPT presentasi dan daftar kehadiran.

b. Pelaksanaan kegiatan

Pada tahap ini mensosialisasikan peran pegadaian syariah dalam meningkatkan perekonomian negara pada saat pandemi kepada para peserta pengabdian masyarakat.

\section{Evaluasi Kegiatan}

Merupakan suatu hal yang penting untuk mengetahui kegiatan yang dilaksanakan berhasil atau tidak. Untuk itu maka dilakukan evaluasi di akhir kegiatan untuk mengetahui tingkat keberhasilan dari kegiatan tersebut.

\section{HASIL DAN PEMBAHASAN}

Pengabdian masyarakat ini merupakan bagian dari kegiatan tri dharma perguruan tinggi sebagai peran aktif dosen dalam memberikan pemahaman masyarakat tentang sebuah kasus yang saat ini sedang terjadi berkaitan dengan penanganan pemerintah tentang permasalahan Covid 19. Pengabdian masyarakat dengan metode kajian ini dilakukan pada 31 Juli 2021. Acara dilaksanakan melalui virtual, yakni memanfaatkan aplikasi Google Meet.

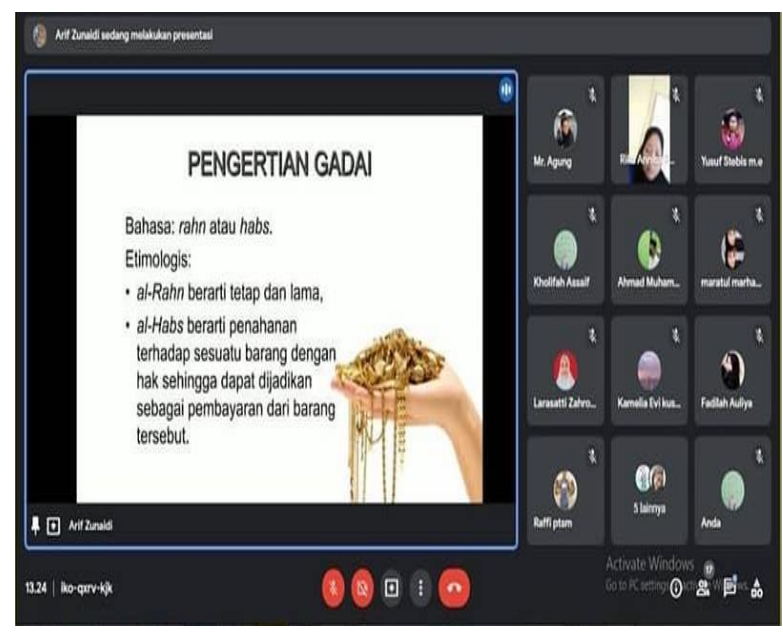

Gambar 1. Penyampaian materi
Pada saat pandemi sekarang ini memang mengharuskan segala acara tidak melibatkan banyak orang untuk berkumpul dalam satu ruangan untuk mencegah kerumunan dan menghambat penyebaran kasus baru virus Covid 19. Acara ini dilaksanakan atas kerjasama antara dua kampus yang berbeda, yakni IAIN Kediri dan Unwaha Jombang. Diikuti oleh 20 peserta yang berasal dari kampus Unwaha, khususnya anggota KORF: Kajian online RnD KSEI HMP ForSESH.

Proses kegiatan pelaksanaan pengabdian ini terbagi atas tiga bagian, antara lain: (1) Sesi awal, yakni sesi pembukaan yang dibuka oleh MC, tilawah. Acara awal berlangsung pada pukul 13.00 hingga $13.30 \mathrm{WIB}$; (2) Sesi kedua adalah sesi inti, dibuka oleh moderator dan dilanjutkan dengan penjelasan oleh pemateri. Pada sesi ini menjelaskan peran Pegadaian Syariah pada perekonomian di Indonesia, khususnya paa saat pandemi Covid 19; (3) Sesi ketiga adalah sesi tanya jawab. Para peserta dapat bertanya secara langsung kepada pemateri tentang permasalahan yang dihadapi oleh para peserta. Banyak yang bertanya dan bercerita tentang pengalaman mereka ketika berhubungan dengan pegadaian syariah.

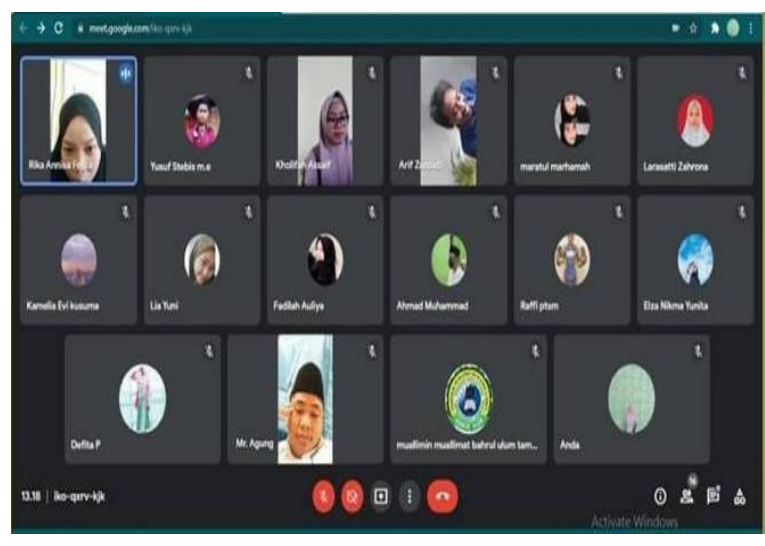

Gambar 2. Peserta Pelatihan

Pengabdian ini merupakan kegiatan yang diselenggarakan secara virtual melalui aplikasi Google Meets. Secara otomatis faktor yang menjadi masalah utama adalah jaringan internet dan perangkat lain yang mendukung, seperti laptop dan handphone android yang memiliki signal kuat. Sehingga kendala yang sering dihadapi pada pengabdian ini adalah jaringan yang kadang tidak stabil menyebabkan peserta kadang keluar dengan sendirinya dari ruang pertemuan (Noviandi et al., 2021). Secara keseluruhan, kegiatan pengabdian ini tidak mengalami gangguan dalam hal jaringan atau pun hal lainnya. Para peserta juga puas dengan 
penyajian yang disampaikan oleh pemateri. Hal itu terlihat dari banyaknya pertanyaan dan keaktifan peserta untuk bertanya dan berbagi pengalaman selama diskusi berlangsung. Pada akhir acara, tim mencoba untuk mencari tingkat kepuasan peserta dengan mengedarkan form kuesiner untuk mengetahui tingkat kepuasan peserta. Dari hal tersebut diketahui, bahwa peserta puas dan memberikan masukan untuk pembahasan yang akan dibahas selanjutnya.

\section{KESIMPULAN}

Secara keseluruhan acara pengabdian masyarakat ini dapat berjalan dengan baik. Peserta antusias dan tertarik dengan tema yang disampaikan oleh pemateri. Dengan adanya pembahasan tema ini para peserta makin memahami tentang peran pegadaian syariah dan peran pemerintah untuk meningkatkan perekonomian negara.

\section{DAFTAR PUSTAKA}

Johnson, E. B. (2011). CTL (Contextual Teaching \& Learning: menjadikan kegiatan belajar-mengajar mengasyikkan dan bermakna. Kaifa.
Noviandi, N., Nisa, P. C., \& Sari, L. P. (2021). Pemanfaatan Aplikasi Zoom dan Google Meet Sebagai Media Dakwah Pada Masa Pandemi Covid-19. Jurnal Abdimas, 7(3), 264-267.

Pegadaian, T. (2020). Driving Sustainability: Laporan Tahunan 2020.

Sari, F. (2020). Outstanding rahn Pegadaian sentuh Rp 6,3 triliun di tahun lalu. Kontan. https://keuangan.kontan.co.id/news/outstan ding-rahn-pegadaian-sentuh-rp-63-triliundi-tahun-lalu

Sugihamretha, I. D. G. (2020). Respon Kebijakan: Mitigasi Dampak Wabah Covid-19 Pada Sektor Pariwisata. Jurnal Perencanaan Pembangunan: The Indonesian Journal of Development Planning, 4(2), 191-206. https://doi.org/10.36574/jpp.v4i2.113

Tune Sumar, W., \& Tune Sumar, S. (2020). Implementasi Program Pengembangan Keprofesian Berkelanjutan Guru melalui Peningkatan Kompetensi Pembelajaran Berbasis Zonasi. Pedagogika, 10(2), 84-94. https://doi.org/10.37411/pedagogika.v10i2. 60. 